\title{
Revisão estratigrafica e faciologia do Grupo Cuiabá no alinhamento Cangas-Poconé, baixada Cuiabana, Mato Grosso
}

\author{
Cláudia do Couto Tokashiki ${ }^{1}$ \& Gerson Souza Saes ${ }^{2}$
}

\begin{abstract}
Resumo O Grupo Cuiabá compreende uma espessa pilha metassedimentar acumulada na margem sudeste do Craton Amazônico e afetado pelo Ciclo Orogênico Brasiliano-Panafricano ( 600 Ma). O estudo de afloramentos em perfis regionais, minas abertas para exploração de ouro e furos de sondagem no Alinhamento Cangas-Poconé cosntituem a base para propor uma divisão litoestratigráfica do Grupo Cuiabá nas formações Campina de Pedras, Acorizal e Coxipó. Ao longo desse alinhamento é reconhecida uma associação de fácies com predomínio de meta-ritmitos com dropstones, com uma forte assinatura magnética, denominada aqui como Fácies Cangas na porção média da Formação Acorizal, possuindo uma provável cronocorrelação com a Fácies Engenho, ambas depositadas sob forte influência glacial. Esta litofácies ocorre associada com (meta) conglomerados, arenitos e pelitos e horizontes subordinados de diamictitos maciços. Esta sucessão é sugestiva da acumulação em ambiente marinho glacialmente influenciado. Os meta-ritmitos são interpretados como depositados durante um longo período de deglaciação, elevação eustática do nível do mar e liberação de clastos grosseiros de massas de gelo flutuantes (icebergs). A pilha sedimentar foi afetada pelo metamorfismo regional em fácies xistos verdes, alcançando Zona da Biotita, deformada em dobras recumbentes e submetida a intensa atividade hidrotermal durante as ultimas fases de deformação, com remobilizaçao de veios de quartzo, sericitizaçao, sulfetação e fluidos carregando ouro. A mineralização aurífera é considerada como o produto de uma combinação de fatores, todos contribuindo para o trapeamento do fluxo dos fluidos hidrotermais, tais como a baixa permeabilidade das rochas encaixantes, a posição estrutural transversal à trajetória do fluxo hidrotermal e o retrabalhamento de um embasamento granito-greenstone fértil na borda sudeste do Cráton Amazônico.
\end{abstract}

Palavras-chave: neoproterozóico, faixa Paraguai, grupo Cuiabá, ouro.

\begin{abstract}
Stratigraphyc revision and facies analysis of Cuiabá Group in the Cangas-Poconé alignment, Cuiabá depression (MT), Brazil. The Cuiabá Group comprises a thick netasedimentary pile accumulated at the southeastern margin of Amazon Craton and affected by the Brasiliano-Panafrican Orogenic Cycle ( $600 \mathrm{Ma})$. The study of outcrops in regional profiles, open pits for gold exploration and drilling cores at Cangas-Poconé Alignment provides the basis for proposing a lithostratigraphic division of the Cuiabá Group into the Campina de Pedras, Acorizal and Coxipó formations. Along this alignment is recognized a facies association with predominance of metaritmites with dropstones, with a very strong magnetic signature denominated here as Cangas Facies on the midlle portion of the Acorizal Formation, encompassing a probable chronocorrelation with the glacially influenced Engenho Facies. This lithofacies ocurrs associated with (meta) conglomerates, sandstones and pellites and subordinated horizons of massive diamictites. This sucession is suggestive of a accumulation on a glacially influenced marine setting. The metarimite are interpreted as deposited during a long period of deglaciation, eustatic rise of sea level and liberation of coarse clasts from floating icemassas (icebergs). The sedimentary pile was affected by regional metamorphism at the greenschist facies reaching the Biotite Zone, deformed in recumbent folds and submitted to intensely hydrothermal activity during the last phases of deformation, with remobilization of quartz veins, sericitization, sulfetation and gold bearing fluids. The gold mineralization is supposed to be the product of a combination of diverse factors all contributing to the trapping of hydrothermal fluid flux, such as the very low permeability of host rocks, it's structural transverse position to the hydrothermal fluid flow path and a reworking of a fertile granite-greeenstone basement terrain of the border of southeastern Amazon Craton.
\end{abstract}

Keywords: neoproterozoic, Paraguai belt, Cuiabá group, gold.

INTRODUÇÃO Há muito tempo nota-se o grande interesse despertado pelas rochas que compõem o Grupo Cuiabá, haja vista a farta literatura, iniciada no século XIX com o Conde Francis de Castelnau (1857) e Evans (1894). Estudos posteriores foram realizados por
Almeida (1948, 1954, 1964, 1965, 1974, 1984, 1985), Vieira (1965), Figueiredo et al. (1974), Ribeiro Filho et al. (1975), Olivatti (1976), Luz et al. (1980), Barros et al. (1982), Alvarenga (1984 e 1988), Alvarenga \& Saes (1992), Alvarenga \& Trompette (1993), assim

1 - Programa de Pós-graduação em Geociências, UFMT, Cuiabá (MT), Brasil. E-mail: claudiatokashiki@gmail.com

2 - Departamento de Recursos Minerais, PPGEC-UFMT, Cuiabá (MT), Brasil. E-mail: gssaes@gmail.com 
como monografias de conclusão do curso de Geologia da UFMT (Freitas inédito) e (Leão \& Dall'Oglio inédito), dissertações de mestrado (Silva 1999), teses de doutoramento (Alvarenga 1990) e relatórios de pesquisas realizadas por empresas de mineração interessadas em avaliar o potencial aurífero da região da Baixada Cuiabana. O Grupo Cuiabá é constituído por metassedimentos clásticos com pequena contribuição química e vulcânica, afetado por várias fases de deformações e metamorfizado na fácies xistos verdes.

O trabalho tem como objetivo a revisão e proposição de uma coluna litoestratigráfica para o Grupo Cuiabá na Baixada Cuiabana e o estudo faciológico de suas rochas no trecho compreendido entre a cidade de
Poconé e o distrito de Cangas, no denominado Alinhamento Cangas-Poconé, orientado $\mathrm{N} 40^{\circ} \mathrm{E}$ e hospedeiro das principais mineralizações da Província Aurífera da Baixada Cuiabana (Paes de Barros 1998) (Fig. 1). As informações compiladas da literatura aliadas ao levantamento de seções geológicas regionais, lograram a reconstituição do empilhamento estratigráfico original, a identificação e interpretação das principais fácies sedimentares e o estabelecimento de unidades e superfícies de correlação para a parte intermediária do Grupo Cuiabá na região. Adicionalmente foram estudados 04 (quatro) testemunhos contínuos de sondagens realizadas nas proximidades de Poconé e Cangas, totalizando cerca de $800 \mathrm{~m}$ de amostragem de subsuperfície, sendo

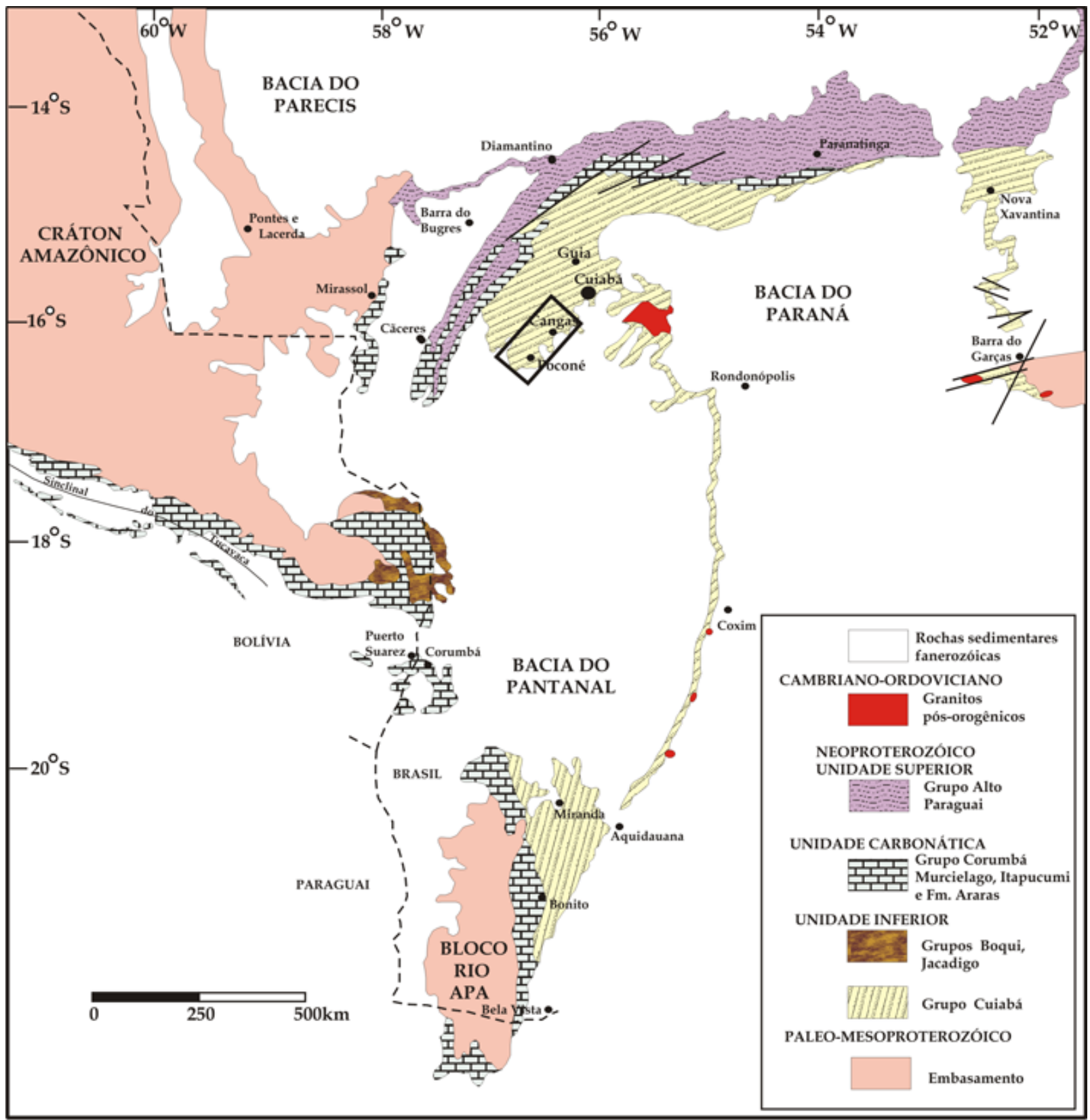

Figura 1 - Mapa geológico da Faixa Paraguai em MT, MS e Bolívia e seção estrutural esquemática (A-B) entre Cuiabá e Mirassol d'Oeste (Alvarenga 1988). O retângulo a sudoeste de Cuiabá assinala a área estudada. 
enfocadas as principais estruturas primárias e associações litológicas, com registro fotográfico e seleção de amostras para estudos petrográficos e geoquímicos. Estes estudos visaram a identificação das paragêneses minerais e composição química ligadas aos protólitos sedimentares, ao metamorfismo regional e ao intenso hidrotermalismo que atuou na área.

CONTEXTO GEOLÓGICO REGIONAL Os cinturões orogênicos do Ciclo Brasiliano-Pan-Africano ( $\sim 600 \mathrm{Ma})$ marcam uma das mais importantes feições tectônicas do embasamento pré-cambriano do território brasileiro. A Faixa Paraguai-Araguaia como definida originalmente por Almeida (1965), constitui um cinturão de dobramentos de destaque na região central do continente sul-americano, bordejando o leste-sudeste do Cráton Amazônico e o leste do Bloco Rio Apa. A descontinuidade geográfica entre os dois segmentos, além de datações radiométricas (Hasui et al. 1980), levaram Silva et al. $(1974)$ e Almeida $(1974,1984)$ à subdivisão deste cinturão em duas unidades: o Cinturão Araguaia/Tocantins, margeando a borda leste do Cráton Amazônico e o Cinturão Paraguai, ao longo da sua borda sudeste. Almeida (1984) subdividiu a Faixa de Dobramentos Paraguai em três zonas estruturais: Brasilides Metamórficas, Brasilides não Metamórficas e Coberturas Brasilianas, renomeadas por Alvarenga (1988) e Alvarenga \& Trompete (1992) como Zona Estrutural Interna, Zona Estrutural Externa e Coberturas Sedimentares de Plataforma respectivamente. Alvarenga $(1988,1990)$ descreve a Faixa Paraguai como um cinturão de dobramentos polifásicos afetado pelo Ciclo Brasiliano e constituído por metassedimentos dobrados e metamorfisados, que em direção ao Cráton Amazônico passam progressivamente a coberturas sedimentares em parte contemporâneas e estruturalmente onduladas, falhadas, mas não metamorfisadas. São características gerais da Faixa Paraguai a forma de um grande arco convexo para o Cráton Amazônico, a intensa deformação linear, presença de falhas inversas e empurrões, dobramento isoclinal e recumbente, escassez de vulcanismo e presença de plutões graníticos em suas zonas internas (Almeida 1984, Alvarenga 1990, Alvarenga \& Trompette 1993).

Um ramo da Faixa Paraguai se estende desde Corumbá através da Bolívia com direção WNW-ESSE, sendo conhecido como Cinturão Tucavaca (Litherland et al. 1986). Este se apresenta como uma grande estrutura sinclinal na Bolívia, recentemente interpretado como um aulacógeno, em contraste com as concepções que consideravam a existência de um cinturão dobrado Brasiliano-Pan-Africano distinto, isolando o Cráton Amazônico do Bloco Rio Apa (Trompette 1994) (Fig. 1). O contexto geodinâmico da Faixa Paraguai ainda é tema controverso. Almeida (1984) sugere que as características litológicas, estruturais e metamórficas do Grupo Cuiabá são compatíveis com bacia do tipo miogeossinclinal, possivelmente passando a condições eugeossinclinais na área hoje oculta sob a Bacia do Paraná. Alvarenga \& Trompette (1992) admitem uma evolução lateral da sedimentação do Grupo Cuiabá e seus equivalentes cratônicos compatível com o desenvolvimento de uma margem passiva na borda oeste de um oceano brasiliano, ou acumulação em borda de um aulacógeno/ rift continental. Contudo, conforme já assinalado por Almeida (1984), o limite arqueado da faixa (convexo para o antepaís cratônico a oeste), parece incompatível com a presença de descontinuidade crustal importante entre as duas unidades geotectônicas, resultando improvável a segunda hipótese aventada por aqueles autores.

\section{ESTRATIGRAFIA DO GRUPO CUIABÁ Almei-} da (1948) descreveu a Série Cuiabá como composta por metassedimentos de baixo grau metamórfico, predominantemente filitos com intercalações de quartzitos, ambos cortados por veios de quartzo "ligados à intrusão granítica de São Vicente". Almeida (1965) ainda identificou na Faixa Paraguai três estágios tectono-estratigráficos: inferior, médio e superior, referentes às variações dos processos de sedimentação influenciados pela evolução miogeossinclinal. $\mathrm{O}$ referido autor ainda reportou as rochas do Grupo Cuiabá, como sendo de depósitos de flysch, originados por correntes de turbidez relacionadas com deslizamentos submarinhos havidos nos fundos instáveis do geossinclineo.

Guimarães \& Almeida (1972) reconheceram cinco conjuntos de rochas separáveis e empilhadas estratigraficamente dentro do Grupo Cuiabá, sendo da base para o topo: Metaconglomerados e quartzitos; Filitos e filitos ardosianos; Quartzitos; Metagrauvacas e metarcóseos, englobados no Grupo Cuiabá indiferenciado; Metassedimentos periglaciais denominados de Formação Coxipó.

Segundo Alvarenga $(1984,1990)$ e Alvarenga \& Saes (1992), a Faixa Paraguai pode ser dividida em quatro grandes grupos cronoestratigráficos: Seqüência Inferior, Seqüência Média Glácio-marinha Turbidítica, Seqüência Média Carbonatada e Seqüência Superior. Estes autores verificaram também os aspectos sedimentológicos presentes nas zonas externa e interna da faixa, mostrando a existência de uma passagem gradual de um ambiente glácio-marinho com correntes de turbidez para um ambiente essencialmente turbidítico em sua zona mais interna, na região de São Vicente (Fig. 2).

Luz et al. (1980) evocam a existência de dois ambientes deposicionais distintos para o Grupo Cuiabá: as sub-unidades 1, 2, 3, 5 e 6 sugerem ambiente marinho onde as instabilidades tectônicas deram origem a correntes de turbidez, e conseqüentes fluxos de lamas. Os turbiditos assim depositados apresentam intercalações de rochas carbonáticas, características dos períodos de quiescência tectônica. Propõem ainda que a fácies conglomeráticas seja o produto de fluxo de detritos, ocasionado por correntes de turbidez, enquanto que o material pelítico evidenciaria períodos de quiescência. Já as sub-unidades 4 e 7 têm sido consideradas como tilitos (Almeida 1965, Hennies 1966) e por outros (Viera 1965) como "pebblymudstones", sugestivos de ambiente marinho em clima frio. Luz et al. (1980) sugeriram para as subunidades $4 \mathrm{e}$ 7 um ambiente glácio-marinho, possivelmente associado 


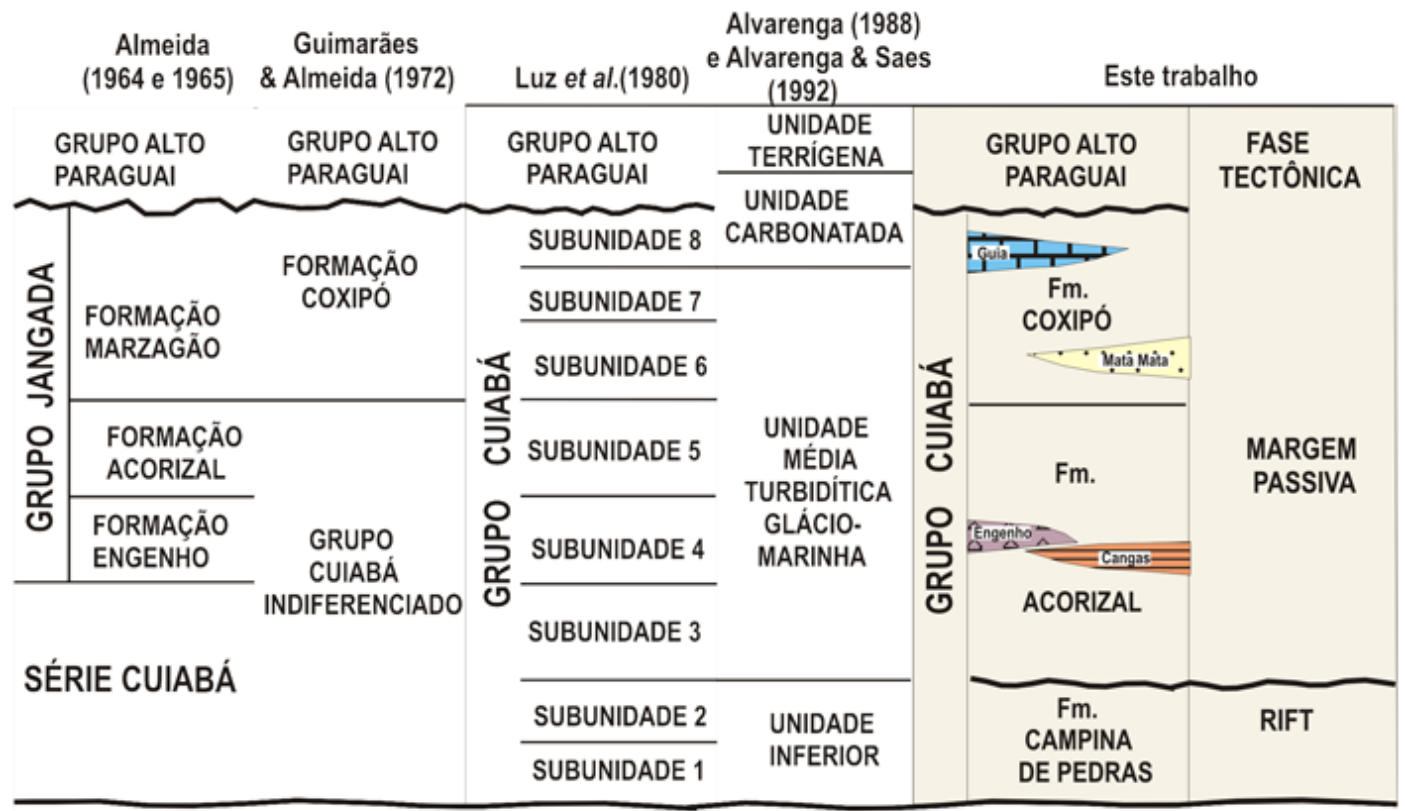

EMBASAMENTO

Figura 2 - Comparação entre as colunas estratigráficas propostas para o Grupo Cuiabá e subdivisão adotada neste trabalho.

a grandes massas de gelo flutuantes.

Na porção leste da faixa (Nova Xavantina, Barra do Garças/MT e Bom Jardim/GO) o Grupo Cuiabá consiste de rochas metassedimentares finas (filitos) e quartzitos associados. Rochas vulcânicas máficas, sedimentos químicos (formações ferríferas bandadas, chert) e camadas de filitos carbonosos limitadas por uma zona de cisalhamento, são relacionadas ao Grupo Cuiabá nas cercanias de Nova Xavantina, na área do Garimpo Araés. Esta associação encontra-se sotoposta e foi desmembrada do Grupo Cuiabá tendo sido denominada Seqüência Metavulcanossedimentar Nova Xavantina por Pinho (1990) e interpretada como uma fase embrionária de abertura de fundo oceânico na Faixa Paraguai ou uma bacia do tipo retroarco (Lacerda Filho et al. 2004). Martinelli et al. (1997) e Martinelli (1998) adotam a mesma interpretação estratigráfica, tendo Martinelli \& Batista (2003) renomeado esta unidade como Seqüência Metavulcanossedimentar dos Araés, constituída da base para o topo de uma Associação Metavulcânica (metabasaltos, metatufos, xistos, metandesitos e lápili-tufos); Associação Química (formações ferríferas bandadas, filitos carbonosos e metacherts); Associação Clástica (metassiltitos, metargilitos e quartzitos).

Revisão estratigráfica do Grupo Cuiabá proposta neste trabalho A coluna estratigráfica apresentada neste trabalho é proposta como uma tentativa de resgate das denominações e seções tipo clássicas da literatura geológica sobre a Faixa Paraguai, sendo abaixo descritas da base para o topo:

A Formação Campina de Pedras é adotada segundo o conceito de Freitas (inédito) englobando as sub- unidades 1 e 2 de Luz et al. (1980) e correspondendo à Unidade Inferior de Alvarenga (1988). Sua denominação foi estabelecida em referência ao vilarejo situado no núcleo e flanco NW da Antiforme do Bento Gomes no município de Poconé (Freitas inédito) e é constituída da base para o topo por espessa $(>2.000 \mathrm{~m})$ seqüência deposicional granocrescente de filitos, filitos grafitosos, intercalações de metarenitos com ciclos de Bouma incompletos, mármores calcíticos e metagrauvacas feldspáticas. A análise da faciologia da Formação Campina de Pedras sugere fortemente um contexto deposicional de lagos profundos, em clima tropical a semi-árido, assoreados por deltas que carreavam detritos do Cráton Amazônico expostos nas ombreiras de bacias tipo rifte, instaladas nos primórdios da fragmentação do Supercontinente Rodínia (<1,0Ga) (Unrug 1997, Brito Neves 1999). Esta seqüência está separada das subunidades sobrepostas por contato brusco e notável mudança litológica, configurando importante quebra no regime deposicional e climático, provavelmente envolvendo discordância estratigráfica (como a que separa os sedimentos lacustres da Fase Rift daqueles da Fase Drift das bacias cretácicas da margem atlântica da América), atualmente mascarada pela intensa deformação de ambos os conjuntos.

A Formação Acorizal (Almeida 1964) é correlacionada com as sub-unidades 3, 4 e 5 de Luz et al. (1980) e à Fácies Intermediária da Unidade Média Turbidítica Glácio-marinha de Alvarenga (1988). Empresta o nome da cidade situada a cerca de $70 \mathrm{~km}$ a norte de Cuiabá, denominação esta anteriormente adotada por Almeida (1964) como unidade basal do Grupo Jangada, abrigando ainda as formações Engenho, Bauxi e Marzagão. É composta predominantemente por depósitos gradacionais rítmicos 
de (meta) conglomerados+arenitos+pelitos, com intercalações subordinadas de meta-ritmitos com clastos pingados, quartzitos e metadiamictitos maciços. Os metadiamictitos são variados quanto ao seu aspecto, destacandose um nível marcante pela coloração cinza-arroxeada da sua matriz, que se estende desde Jangada, onde apresenta espessura estimada de cerca de $300 \mathrm{~m}$, até próximo ao trevo de Sete Porcos na Br-070, onde possui espessuras da ordem de alguns metros, desaparecendo por completo nos arredores de Cuiabá e Poconé. Este nível de metadiamictitos foi registrado por Almeida (1964), que the atribuiu a denominação de Formação Engenho (aqui redefinida como Fácies Engenho), constituinte do Grupo Jangada e individualizado por Luz et al. (1980) como sub-unidade 4. Os meta-ritmitos com clastos pingados do alinhamento Cangas-Poconé são aqui denominados de Fácies Cangas e interpretados como variação faciológica cronocorrelata da Fácies Engenho, em virtude da sua posição estratigráfica (contato entre as sub-unidades 3 e 5 de Luz et al. 1980) e conspícuo caráter glaciogênico de ambas. A Formação Acorizal recobre a Unidade Campina de Pedras em aparente discordância e representa a pilha sedimentar gláciomarinha acumulada em uma margem continental do tipo Atlântico, documentando os depósitos da Fase Drift da evolução tectônica da Margem Paraguai.

A Formação Coxipó (Guimarães \& Almeida 1972) é composta predominantemente de filitos conglomeráticos, metarenitos, quartzitos, mármores e me- tadiamictitos petromíticos, ressaltando-se uma considerável variação litológica em toda a sua extensão. Corresponde parcialmente à Formação Marzagão de Almeida (1964), às sub-unidades 6 e 7 de Luz et al. (1980) e à Fácies Proximal da Unidade Turbidítica Glácio-marinha de Alvarenga (1988). Abriga também a Fácies Guia (mármores calcíticos e dolomíticos aflorantes na Sinclinal da Guia) e os quartzitos que formam o alinhamento de serras que se estende da Serra de São Vicente até Barão de Melgaço (Fácies Mata-Mata) (Fig. 3).

\section{ARCABOUÇO ESTRUTURAL DA BAIXADA}

CUIABANA As feições estruturais observadas nas rochas do Grupo Cuiabá na Baixada Cuiabana, em escala micro, meso e macroscópica permitiram caracterizar com base em critérios de superposição, o efeito de quatro fases de deformação. Dentre as estruturas identificadas na área, destaca-se a foliação principal que ao longo de uma seção de NW para SE, varia de mergulho íngreme para SE, passando por vertical, até alcançar mergulho para NW. Esta variação parece estar acompanhada de um aumento na intensidade da deformação de NW para SE e mudança da orientação da lineação de estiramento. Com base na variação da atitude da foliação principal a área é dividida em dois domínios para facilitar a descrição de suas estruturas: Domínio NW (DNW), onde a foliação Sn mergulha para SE, e Domínio SE (DSE) no qual a foliação mergulha para NW

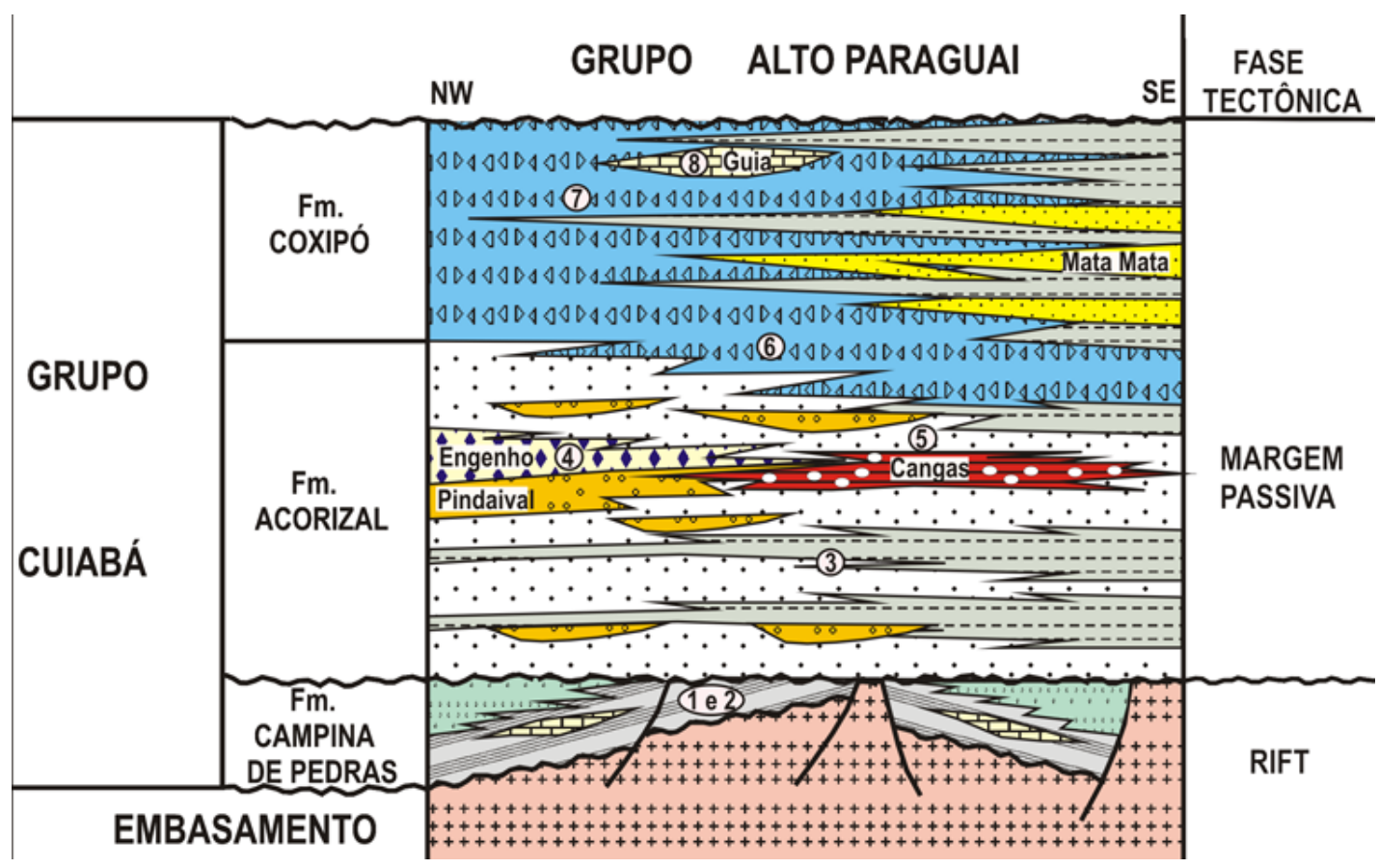

Figura 3 - Carta estratigráfica da Faixa Paraguai para a região da Baixada Cuiabana. Os números correspondem às sub-unidades de Luz et al. (1980). 1 e 2 -Filitos intercalando filitos grafitosos, mármores e metagrauvacas; 3 e 5 - Metaconglomerados, metarenitos e filitos gradacionais, metarcóseos e quartzitos; 4-Metadiamictitos (Engenho) e meta-ritmitos arenopelíticos com "dropstones" (Cangas); 6, 7 e 8 -Filitos, metadiamictitos, quartzitos (Mata-Mata) e mármores (Guia). 
(Silva 1999). O exame das rochas do Grupo Cuiabá é dificultado pelo alto grau de alteração, visto que a maior parte dos afloramentos está alterada ou encoberta, ora por uma capa de laterita, ora por sedimentos recentes, sendo extremamente rara a exposição de rocha sã.

Para Luz et al. (1980) a deformação da faixa móvel foi de natureza polifásica, originando três fases de deformação holomórfica em escala regional nos metassedimentos do Grupo Cuiabá. A primeira, além de dobrar as rochas desse grupo, provocou o metamorfismo regional de fácies xistos verdes, com conseqüente segregação de veios de quartzo que se alojaram paralelamente à foliação S1. A segunda fase originou dobras isoclinais assimétricas e recumbentes, envolvendo os acamamentos transpostos, e as dobras intrafoliais, e também formação de nova foliação $\mathrm{S} 2$ superimposta à primeira. Finalmente a terceira fase manifestou-se fundamentalmente nas seqüências plásticas, que localmente chega a transpor a foliação $\mathrm{S} 2$, formando uma clivagem de crenulação pronunciada e um novo elemento planar S3.

FACIOLOGIA E ESTRATIGRAFIA DO GRUPO CUIABÁ AO LONGO DO ALINHAMENTO CANGAS/POCONÉ Na região de Cangas-Poconé o Grupo Cuiabá está representado pelas sub-unidades 3, 4 e 5 (Luz et al. 1980), Fácies Intermediária da Unidade Média Turbidítica Glácio-marinha de Alvarenga (1988) ou Formação Acorizal (Almeida 1964 e este estudo) (Fig. 4). Os dados obtidos em cavas de garimpos e testemunhos de sondagem confirmam a presença das sucessões rítmicas em várias escalas da Formação Acorizal (Unidade Ribeirão Figueira de Freitas inédito). A imagem de satélite da figura 5 indica um controle estrutural para as mineralizações auríferas, vinculadas aos filões de direção NW (direção das cavas), porém distribuídas ao longo de uma estreita faixa de direção NE, coincidente com a área de ocorrência da Fácies Cangas, fato sugestivo de forte controle estratigráfico na precipitação dos fluidos hidrotermais.

A macroestruturação do alinhamento CangasPoconé, difere substancialmente das demais regiões de ocorrência do Grupo Cuiabá, sendo caracterizada por grandes dobras recumbentes, com a foliação plano axial S1 normalmente paralela à estratificação primária e mergulhando com baixos ângulos para SE (Fig. 6), comportamento anômalo este já documentado por diversos autores (Pires et al. 1986, Silva 2006, Leão \& Dall'Oglio inédito).

Estudos geofísicos realizados na área demonstraram a presença de uma zona linear NE com fortes anomalias de suscetibilidade magnética e condutividade elétrica, coincidentes com a zona mineralizada, denominada de Zona Magnética e atribuída por Leão \& Dall'Oglio (inédito) à presença de filitos magnetíticos em sub-superfície.

Fácies sedimentares $\mathrm{O}$ estudo de cavas de garimpos, raros afloramentos e descrição dos testemunhos de sondagem 3, 5, 8 e 10 (Fig. 4) permitiram a identificação de uma associação de três litofácies sedimentares principais, geneticamente relacionadas e que fornecem elementos de apoio para a proposição de um modelo deposicional deste intervalo estratigráfico do Grupo Cuiabá: i) (meta) conglomerados+arenitos+pelitos em ciclos métricos granodecrescentes; ii) meta-ritmitos arenopelíticos com clastos pingados; iii) metadiamictitos maciços.

(META) CONGLOMERADOS + ARENITOS + PELITOS GRADACIONAIS Esta litofácies é registrada em sub-superfície em todos os testemunhos estudados, especialmente no furo FPO-5 (Fig. 7) no qual é a unidade dominante e raramente é observada em cavas. É caracterizada pela alternância rítmica de conglomerados polimíticos, clasto-sustentados, maciços, passando superiormente em contato gradacional, para arenitos maciços ou laminados e culminando com espessos pacotes de pelitos, maciços e, mais raro, finamente laminados (Fig. 8). Os clastos maiores têm naturezas diversas, incluindo seixos de granito, gnaisse, quartzito, metabásica e rocha carbonática. Apresentam variados graus de deformação, desde horizontes com a forma original dos clastos preservada (Fig. 8-B e E) até zonas de alto strain, com seixos estirados e sombras de pressão bem desenvolvidas (Fig. 8-D). Os metapelitos apresentam intervalos calcíferos, textura mosqueada conferida por fenoblastos de óxido de ferro e aspecto nodular (Fig. 8-F). Os teores dos principais óxidos mostram pequenas variações, à exceção do intervalo de $30,5 \mathrm{~m}$ correspondente a um veio de quartzo sulfetado, se refletindo nos teores mais altos de sílica, ferro e potassa. O horizonte analisado aos $98 \mathrm{~m}$ corresponde a filitos laminados magnetíticos com o conseqüente enriquecimento em alumina e ferro. As características desta litofácies permitem sua correlação com as Fácies Intermediárias da Unidade Média Turbidítica Glaciogenética de Alvarenga (1988), conforme documentadas nas proximidades de Acorizal e detalhadamente descrita por Freitas (inédito) como componente principal da Unidade Ribeirão Figueira no flanco NW da Antiforme do Bento Gomes. Ambos os autores admitem sua origem a partir de materiais glaciais retrabalhados por correntes de turbidez.

META-RITMITOS ARENOPELÍTICOS COM CLASTOS PINGADOS Esta litofácies apresenta-se em todas as cavas de garimpo ao longo do Alinhamento CangasPoconé, além das grandes espessuras amostradas nos testemunhos FPO-3,8 e 10 (Figs. 9, 10, 11 e 12). É essencialmente constituída por delgadas $(\sim 3 \mathrm{~cm})$ intercalações de finas lâminas de metapelitos escuros (não raro carbonosos e ferruginosos) e lâminas de metarenitos finos de cores claras (amarelo, cinza, rosa). Apresentam em geral poucos clastos pingados, que podem variar de centimétricos a métricos e incluem fragmentos diversos, predominando os clastos de rochas plutônicas ácidas (granitos e gnaisses). Na sondagem FPO-10, cerca de $10 \mathrm{~km}$ a sudoeste de Cangas (Fig. 4) esta litofácies intercala níveis delgados de metadiamictitos maciços, arroxeados e com abundantes clastos angulosos de rocha granítica e carbonática (Fig. 10-B). Os meta-ritmitos apresentam aspecto mosqueado, conferido por por- 


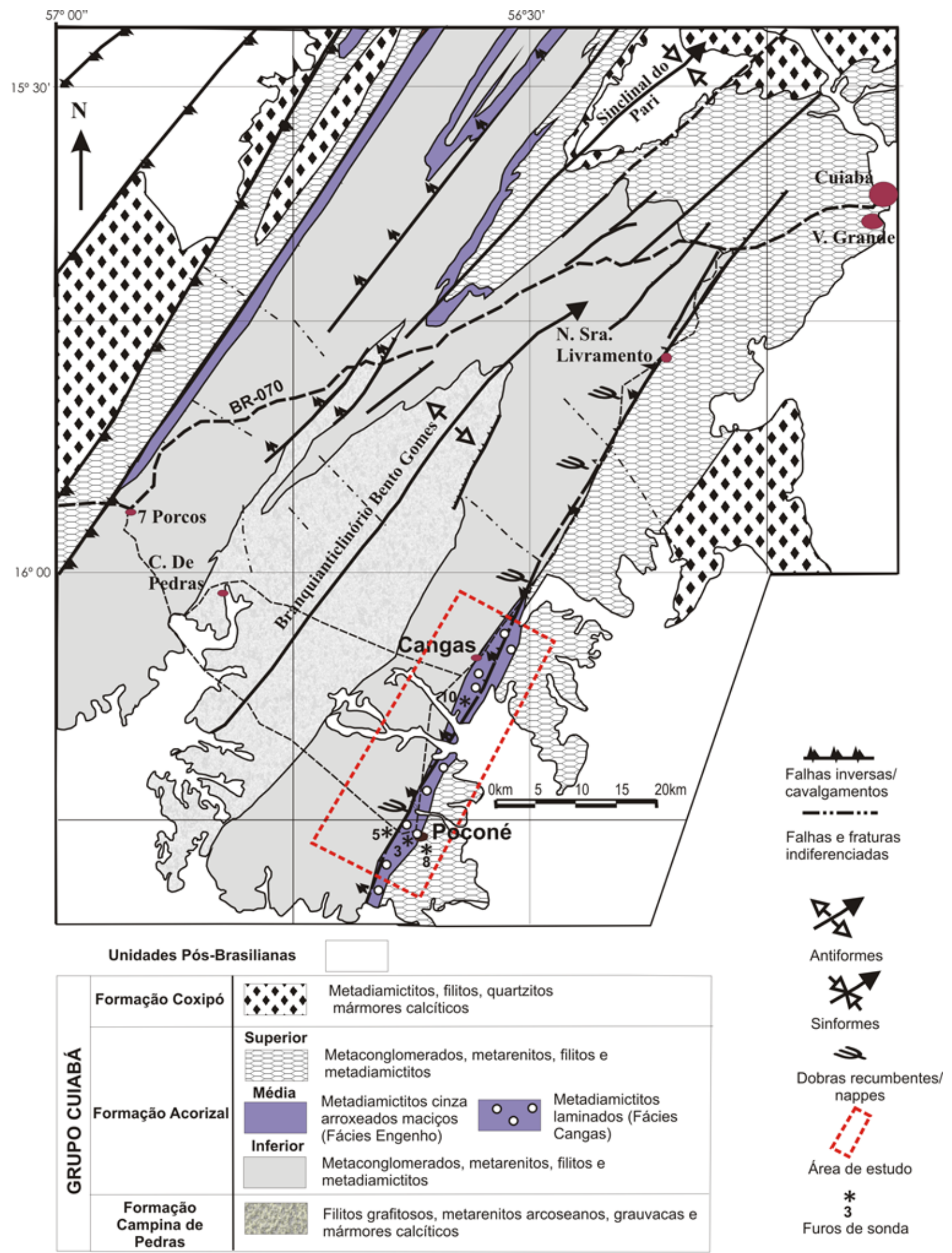

Figura 4 - Esboço geológico de parte da Baixada Cuiabana, destacando a área do alinhamento Cangas/Poconé (adaptado de Luz et al. 1980 e Alvarenga 1988).

firoblastos de óxido de Ferro, em geral limonitizados, níveis calcíferos e outros ricos em hematita e magnetita (Figs. 9 e 10). Os níveis ricos em magnetita e hematita são detectados pela análise química dos principais óxidos, apresentando teores de $\mathrm{Fe} 2 \mathrm{O} 3$ de até $\sim 50 \%$ em algumas amostras ( Figs. 9, 11 e 12).
METADIAMICTITOS MACIÇOS Os metadiamictitos são observados como litofácies subordinadas no testemunho FPO-10, e FPO-05, porém ocorrendo em aproximadamente igual proporção aos diamictitos laminados nos testemunhos FPO-03 e 08 . Os contatos com as demais fácies são abruptos e consistem de rochas com abundante matriz de coloração arroxeada, conteú- 


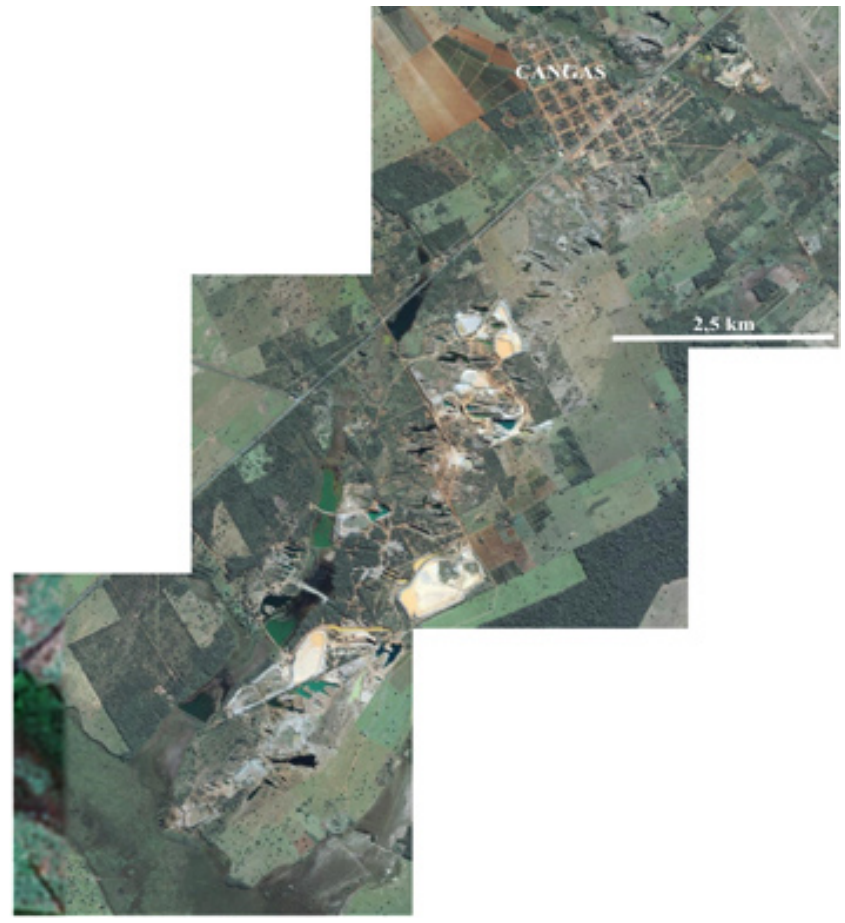

Figura 5 - Imagem da região aurífera de Cangas, destacando-se a orientação NE do Alinhamento Cangas Poconé (controle estratigráfico?) e a orientação $N W$ das cavas de garimpos. do variável de clastos de rocha carbonática, granitos e quartzitos, angulosos e dispersos na matriz areno-siltoargilosa. (Figs. 9, 10, 11 e 12).

CONTEXTO DEPOSICIONAL Os meta-ritmitos grossos (metaconglomerados+arenitos+pelitos) são interpretados como acumulações torrenciais em debris aprons na desembocadura de túneis sub-glaciais ( $s u$ baqueous glacial outwash) no contato geleira-oceano. Os espessos horizontes de metapelitos associados estão provavelmente relacionados à chuva de detritos finos colocados em suspensão pelas águas doces de fusão (Fig. 13). Os meta-ritmitos areno-pelíticos com clastos pingados podem representar os depósitos distais dos meta-ritmitos grossos ou alternativamente, períodos de recrudescimento do recuo das geleiras, com subida do nível do mar. Os níveis enriquecidos em óxidos de Ferro podem representar precipitação do metal durante os períodos de deglaciação, elevação eustática do nível do mar e liberação pelas geleiras de águas frias ricas em $\mathrm{O}_{2}$ dissolvido. As camadas de diamictitos maciços são considerados como depósitos de fluxos gravitacionais subaquosos, escorregamentos (slumps), fluxos de massa ou fluxos de detritos em declives submarinos (Coussot \& Meunier 1996, Eyles \&Eyles 2000), resultando na ressedimentação de uma área fonte heterolítica constituída por uma variedade de fácies de cascalho, areia e lama.
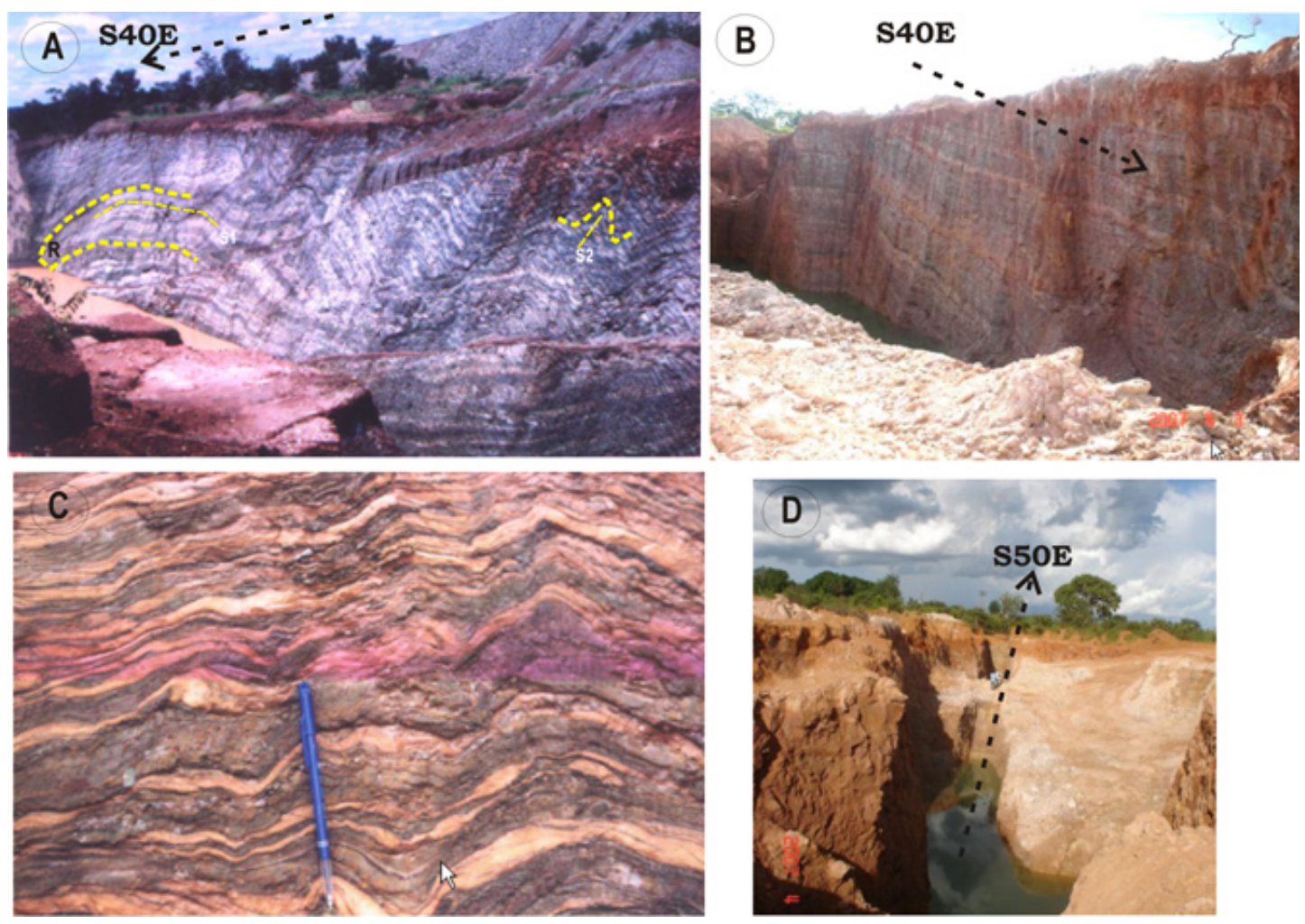

Figura 6 - Meta-ritmitos areno-pelíticos com clastos pingados da Fácies Cangas em cavas de garimpos na região de Cangas: A) Padrão recumbente (R) das dobras Dl afetadas por redobramento co-axial D2; B) Estrutura monoclinal com baixo mergulho para SE; C) Detalhe da estrutura ritmica; D) Filão de quartzo aurífero com orientação transversal à estrutura regional. 

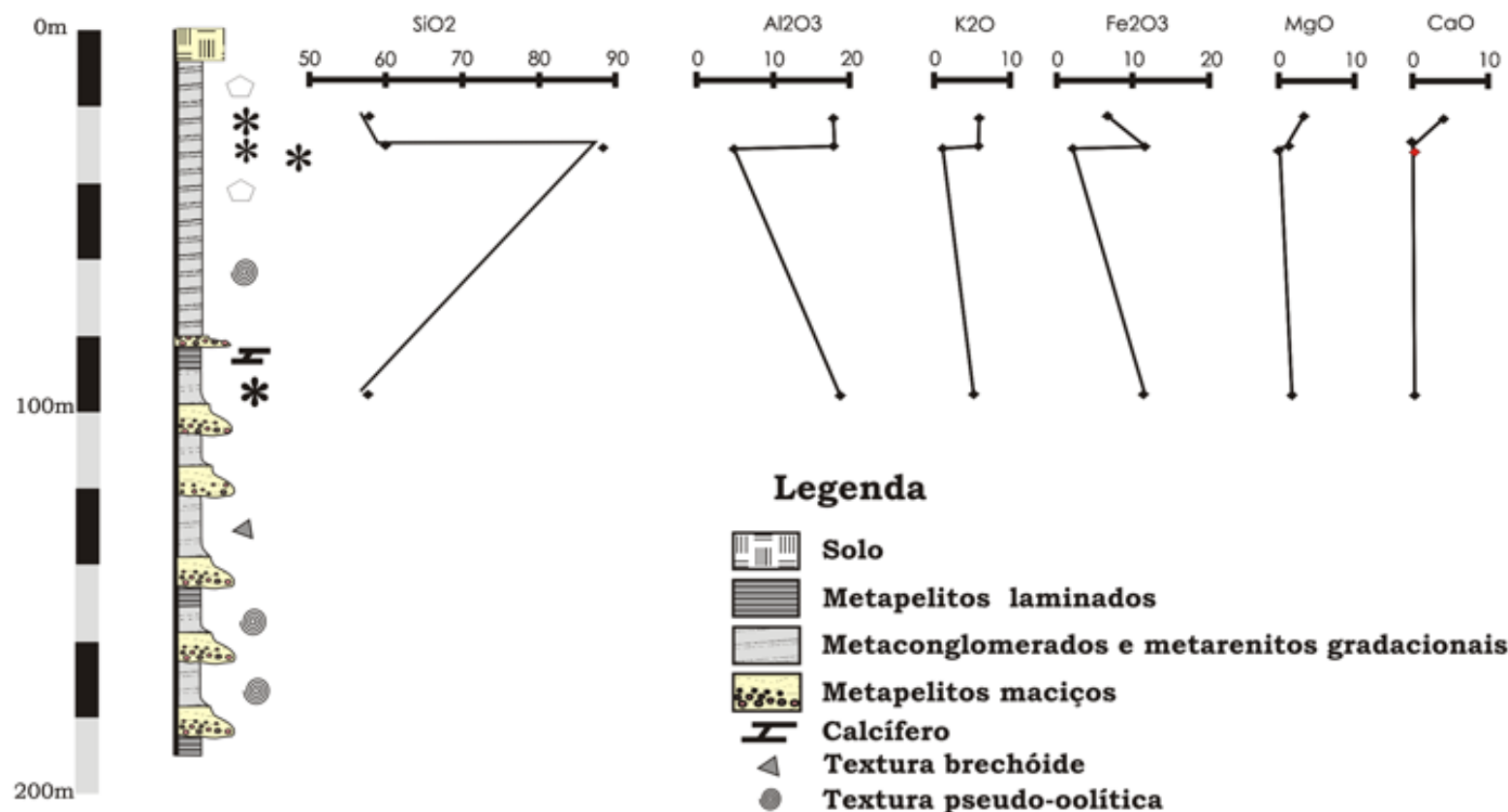

\section{Legenda}

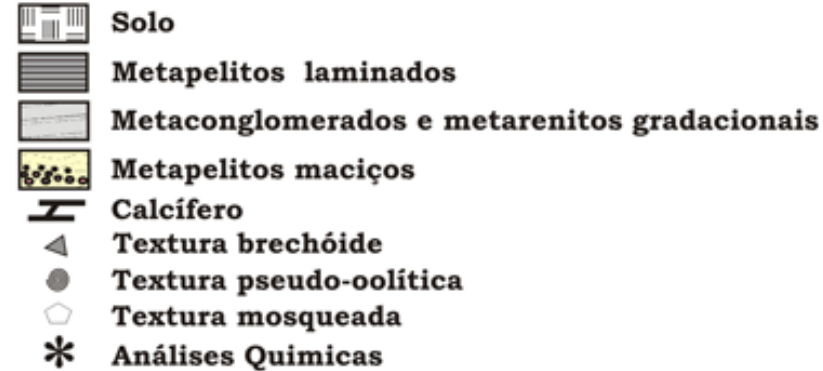

Figura 7 - Perfil litológico do testemunho de sondagem FPO-05 mostrando o predomínio das fácies de metaconglomerados + metarenitos +filitos em ciclos granodecrescentes e variações da porcentagem dos principais óxidos.
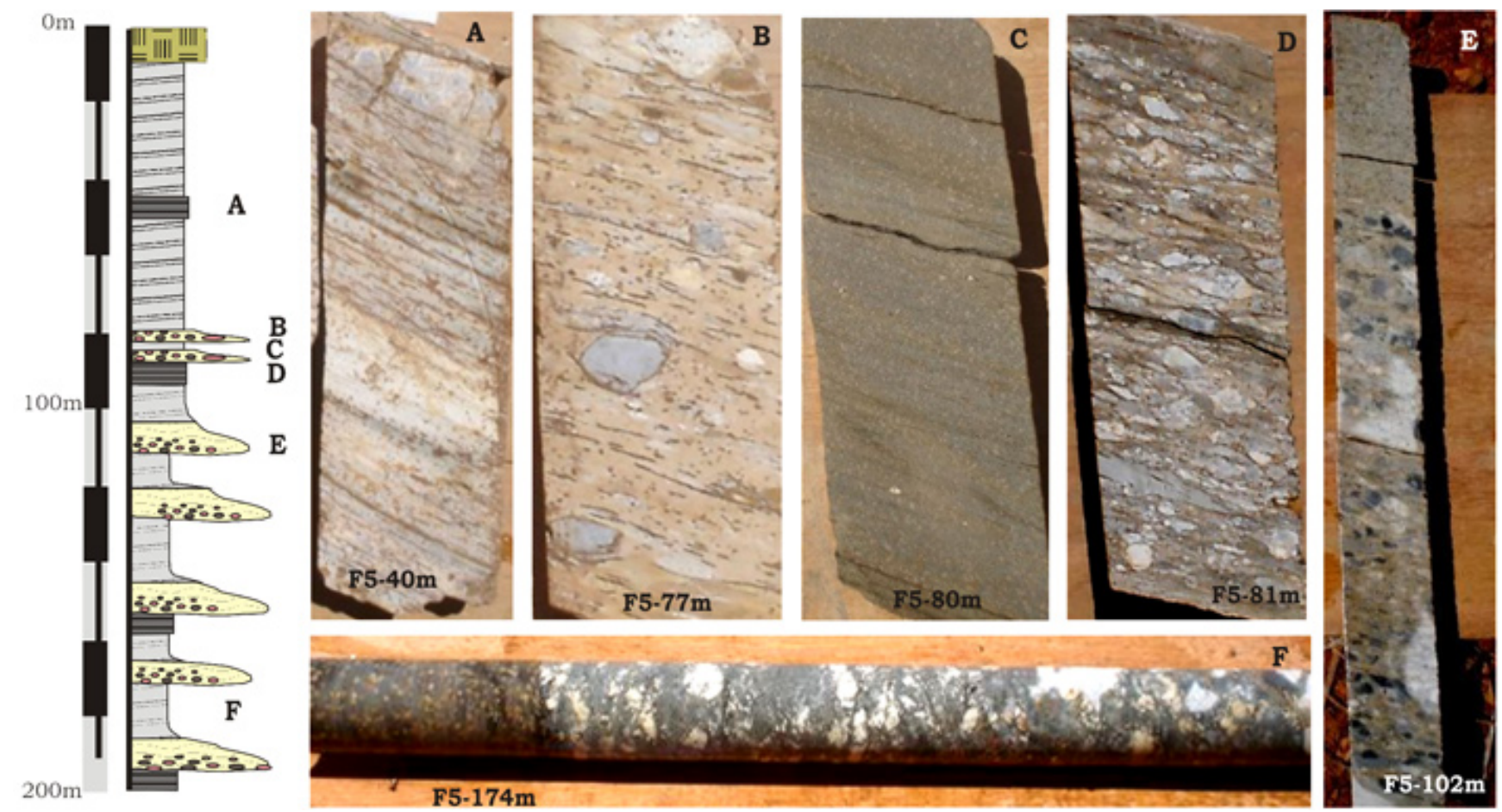

Figura 8 - Principais litofácies no testemunho de sondagem FPO-05: A) Metapelitos laminados; B) Metaconglomerados com abundantes clastos de rocha carbonática; C) Metarenitos laminados; D) Metaconglomerados deformados em zonas de alto strain; E) Estrutura gradacional entre metaconglomerados e metarenitos; $F$ ) Metapelitos com aspecto nodular. 


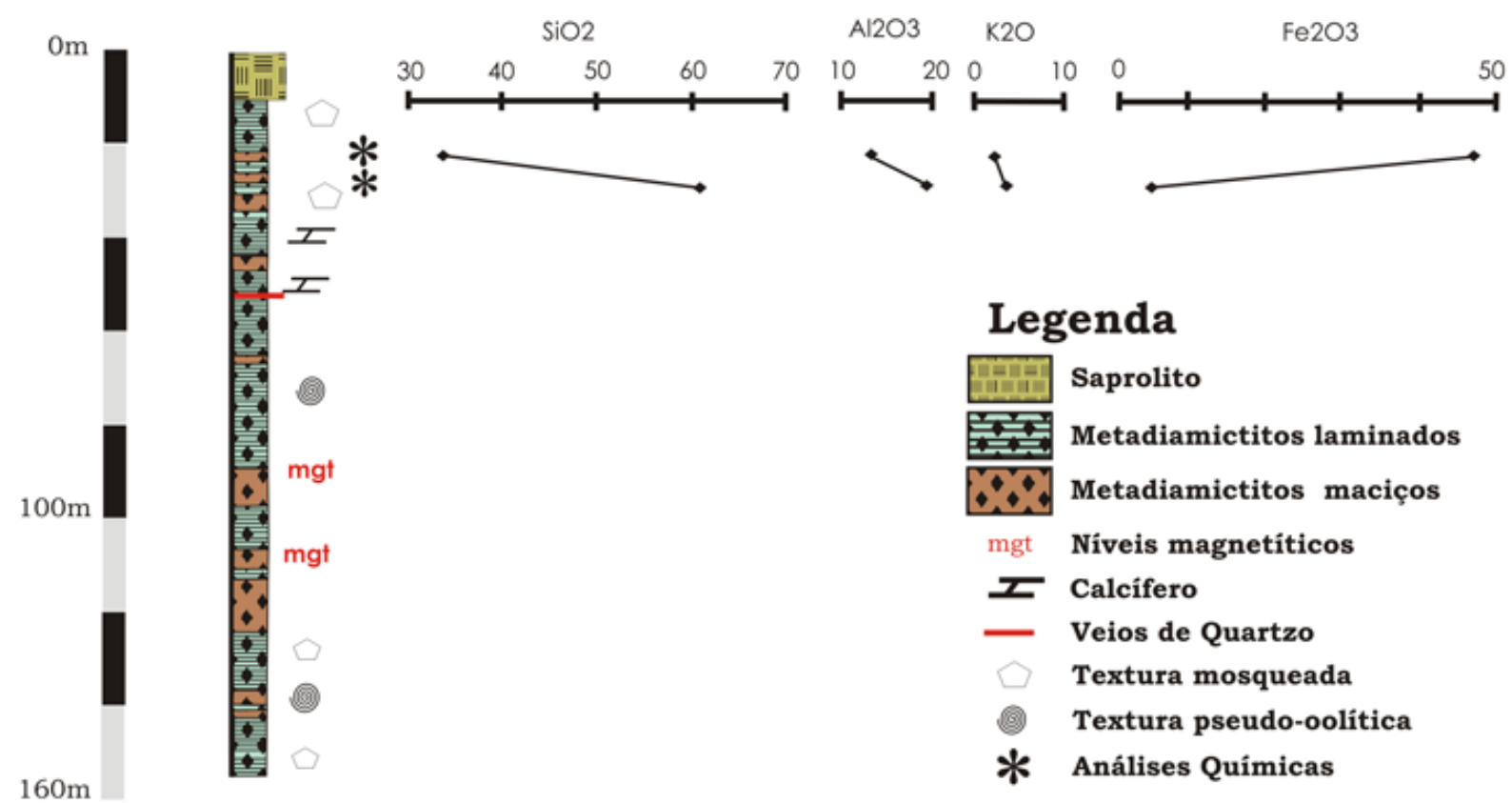

Figura 9 - Perfil litológico do testemunho de sondagem FPO-10, mostrando o predomínio dos metaritmitos com clastos pingados e metadiamictitos maciços e porcentagens dos principais óxidos.

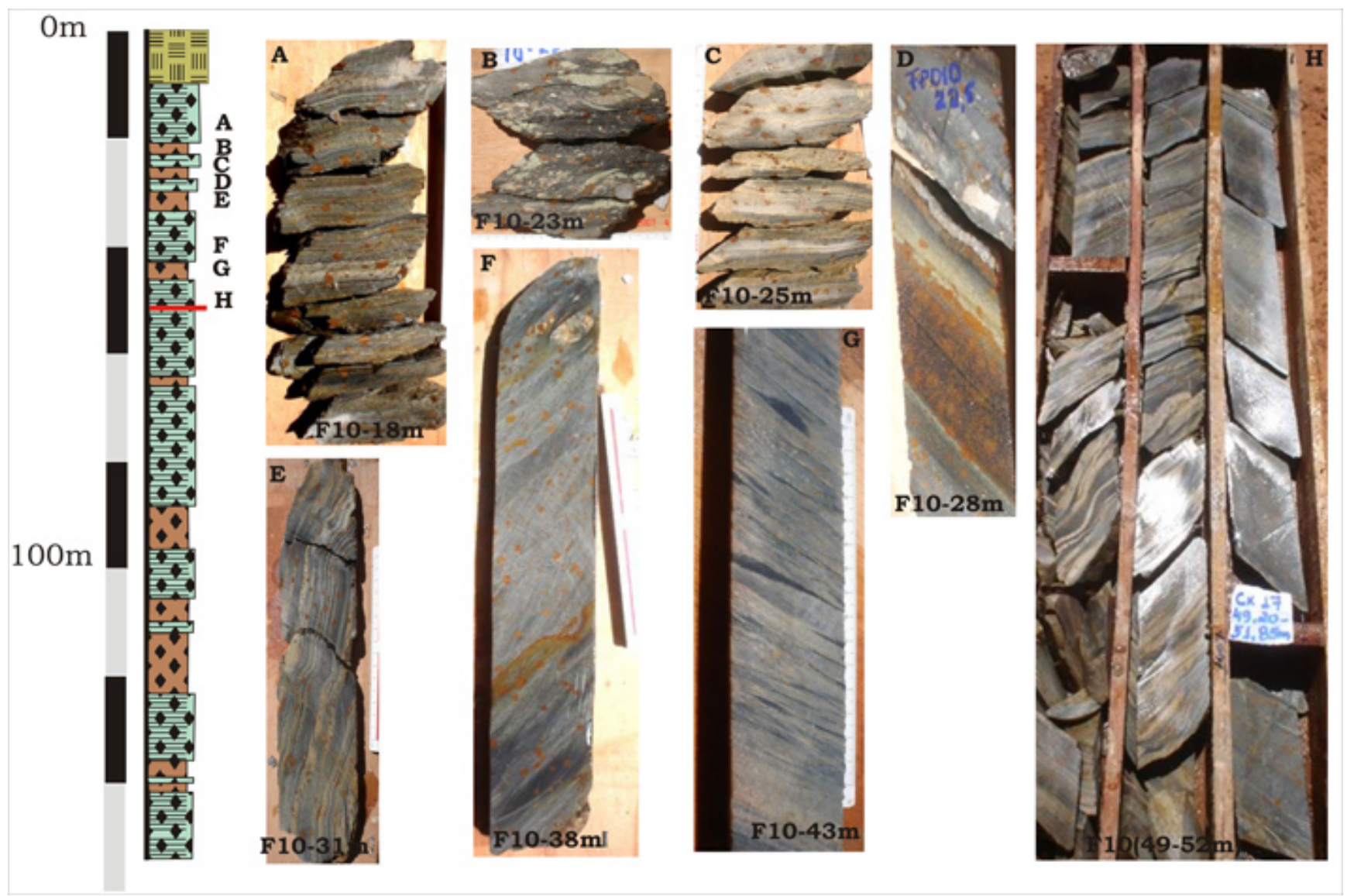

Figura 10 - Principais litofácies do testemunho de sondagem FPO-10: A, C, H, E - Meta-ritmitos arenopelíticos com textura mosqueada; B) Metadiamictitos com abundantes clastos de rocha carbonática; $D, G)$ Niveis de magnetititos interestratificados com (meta) ritmitos/diamictitos; E) Estrutura gradacional entre metaconglomerados e metarenitos; F) Metapelitos magnéticos com clasto isolado de granito. 

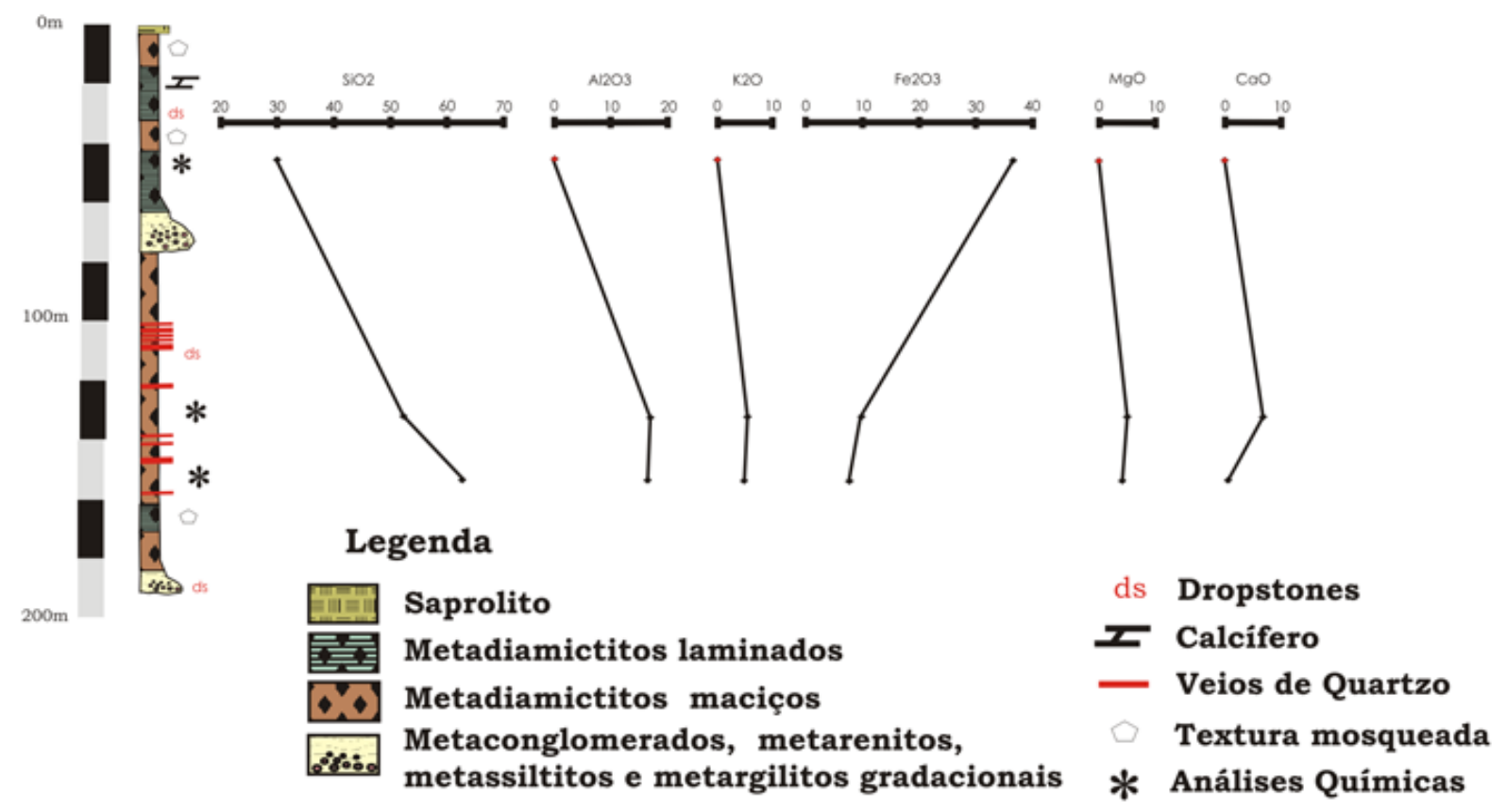

Figura 11 - Perfil litológico do testemunho de sondagem FPO-03, caracterizado por intercalações de diamictitos maciços, laminados e ciclos gradacionais de metaconglomerados, metarenitos, metapelitos e porcentagens dos principais óxidos.

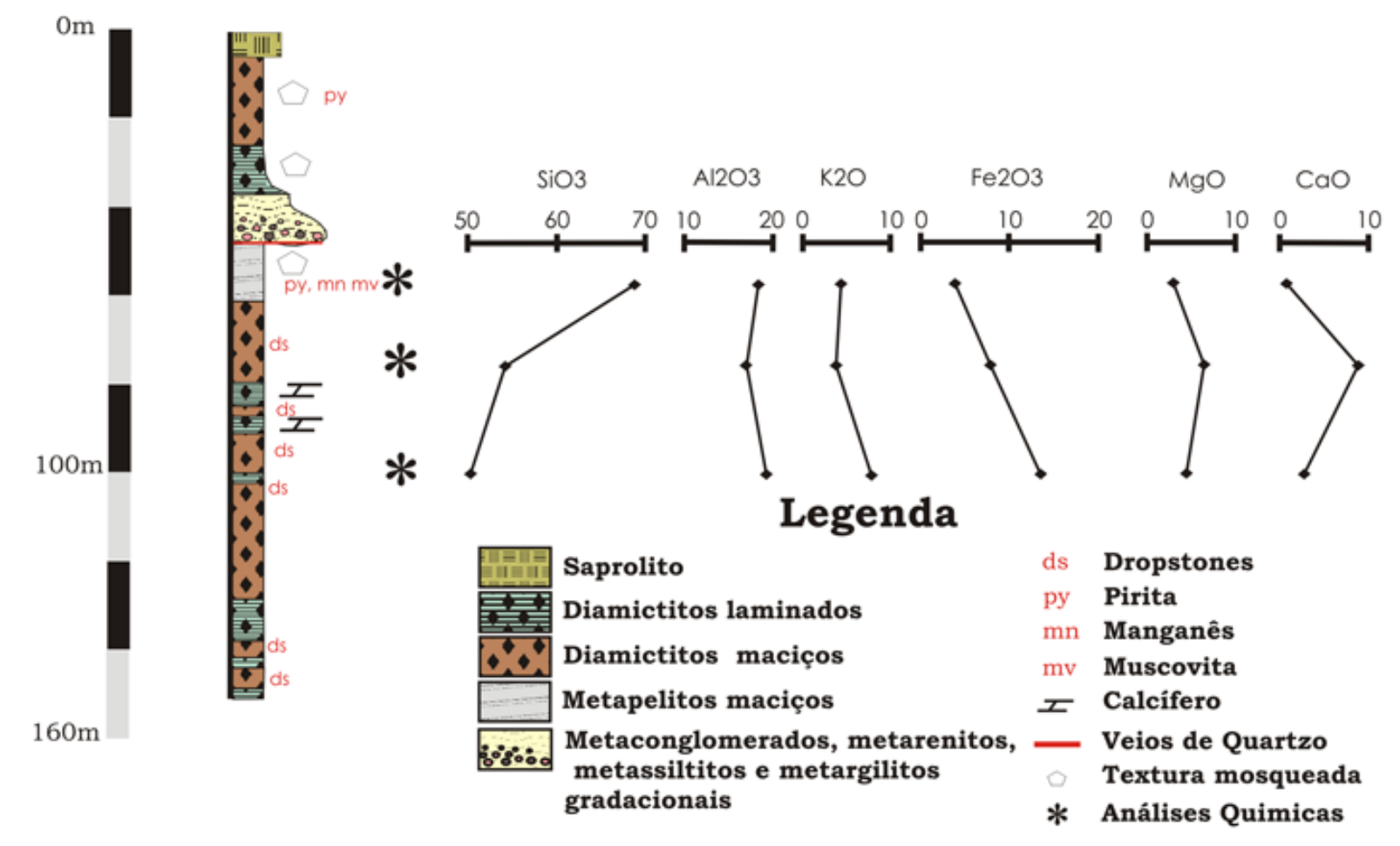

Figura 12 - Perfil litológico do testemunho de sondagem FPO-08 mostrando o predomínio de diamictitos maciços, laminados, intercalações das fácies de metaconglomerados + metarenitos + filitos, $e$ variações dos principais óxidos.

A Formação Port Askaig na Escócia (Aumad \& Eyles 2006) e o Grupo Rapitan nas Montanhas MacKenzie no Alaska (Narbone \& Aitken 1995) podem ser considera- dos exemplos análogos dos depósitos glácio-marinhos do Grupo Cuiabá na região do Alinhamento CangasPoconé. 


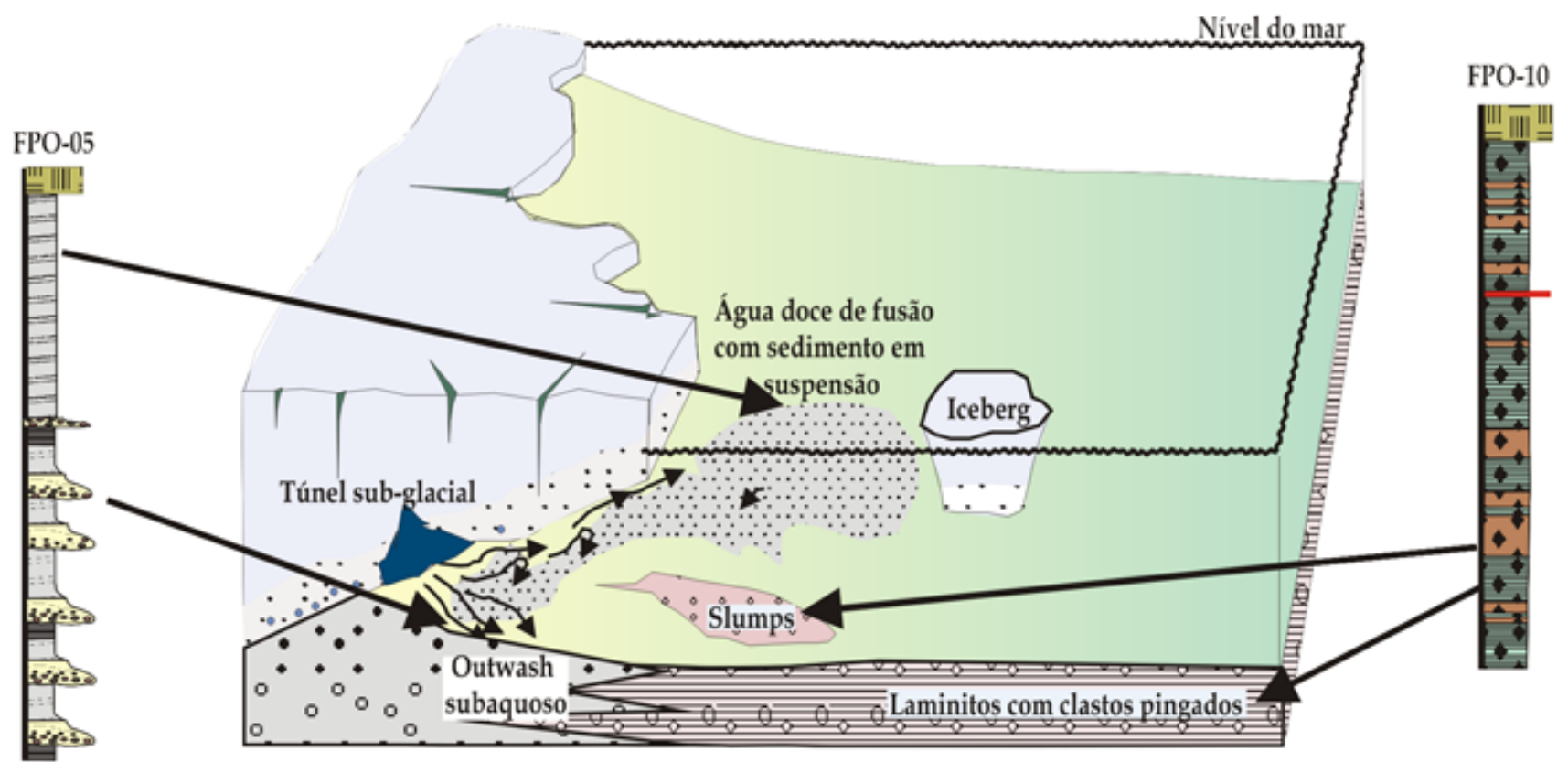

Figura 13 - Modelo deposicional esquemático das principais litofácies da Formação Acorizal no alinhamento Cangas/Poconé (Modificado de Freitas inédito).

Petrografia Os componentes petrográficos observados nos metapsamitos e metapsefitos mostram a tendência composicional fortemente híbrida arcoseana e lítica sedimentar destas rochas, tais como a presença de clastos de granitos, gnaisses e feldspatos, metabásicas, rochas areníticas e carbonáticas (Figs. 14-A e C), demonstrando sua derivação a partir de um embasamento granitognáissico (Cráton Amazônico), recoberto por unidades (meta?) sedimentares. Estas rochas revelam ainda uma natureza texturalmente imatura, com grãos angulosos e matriz argilosa recristalizada como muscovita e biotita.

As texturas observadas foram do tipo palimpséstica (blastopsefítica-psamítica), na qual é ainda possível reconhecer uma distribuição bimodal do tamaho dos grãos, a moda principal na faixa de $0,4 \mathrm{~mm}$ e uma moda secundária com seixos de em média de $4 \mathrm{~cm}$. Textura glanoblástica e lepidoblástica são comuns, com as palhetas de micas e óxidos de Ferro orientados segundo $\mathrm{S}_{1}$ redobradas pela crenulação, com discreto desenvolvimento de recristalização ao longo do seu plano axial. Em algumas amostras verifica-se textura flaser ou oftalmítica com sombras de pressão nas extremidades dos porfiroclastos e o desenvolvimento de franjas de biotita e muscovita ou quartzo nas extremidades menores dos porfiroclastos (Fig. 14-A e B).

A paragênese metamórfica, constituída por biotita-muscovita-Kfeldspato-plagioclásio-quartzo indica condições compatíveis com a Fácies Xistos Verdes, Zona da Biotita (Fig. 14-D e E) e o grau de alteração por hidrotermalismo é evidenciado pela presença de se ricita+magnetita+pirita+carbonatos (Fig 14-G). Os níveis caracterizados por aspecto mosqueado apresentam abundantes porfiroblastos de óxido de Fé sin-cinemáticos, transpostos pela foliação principal S1 (Fig. 14-F).
DISCUSSÃO E CONCLUSÕES O estudo permitiu propor a subdivisão do Grupo Cuiabá em três unidades litoestratigráficas formais (formações), separadas entre si por importantes quebras no regime deposicional preservado (discordâncias?), cujas denominações foram resgatadas com modificações de seções tipo e descrições clássicas da literatura sobre a Faixa Paraguai, as Formações Campina de Pedras (Freitas inédito), Acorizal (Almeida 1964) e Coxipó (Guimarães \& Almeida 1972). As unidades reconhecidas possuem caráter de seqüências estratigráficas, podendo ser subdivididas em outras de menor hierarquia com o reconhecimento de ciclos de afogamento e superfícies de erosão internas às unidades maiores.

A Formação Campina de Pedras registra os primeiros estágios da evolução tectono-sedimentar da Margem Passiva Paraguai após o início da dispersão do Supercontinente Rodínia Nesta fase são implantados sistemas de rifts na borda SE do Cráton Amazônico, onde se acumularam sedimentos continentais lacustres, ricos em carbono orgânico. As metagrauvacas do topo da sucessão representam a progradação de lobos deltáicos assoreando a bacia lacustre ao final do soerguimento e erosão das ombreiras dos rifts.

A Formação Acorizal corresponde à às sub-unidades 3, 4 e 5 de Luz et al. (1980), consistindo de metaritmitos em diferentes escalas associados a diamictitos. Por sua importância econômica foi individualizada uma associação de fácies sedimentares na porção intermediária da Formação Acorizal, denominada Fácies Cangas. É composta por ritmitos grossos e finos, intercalando diamictitos maciços, com fortes evidências de sedimentação glacialmente influenciada. A litofácies de diamictitos laminados corresponde à Zona Magnética de Leão \& Dall'Oglio (inédito) marcada por níveis 

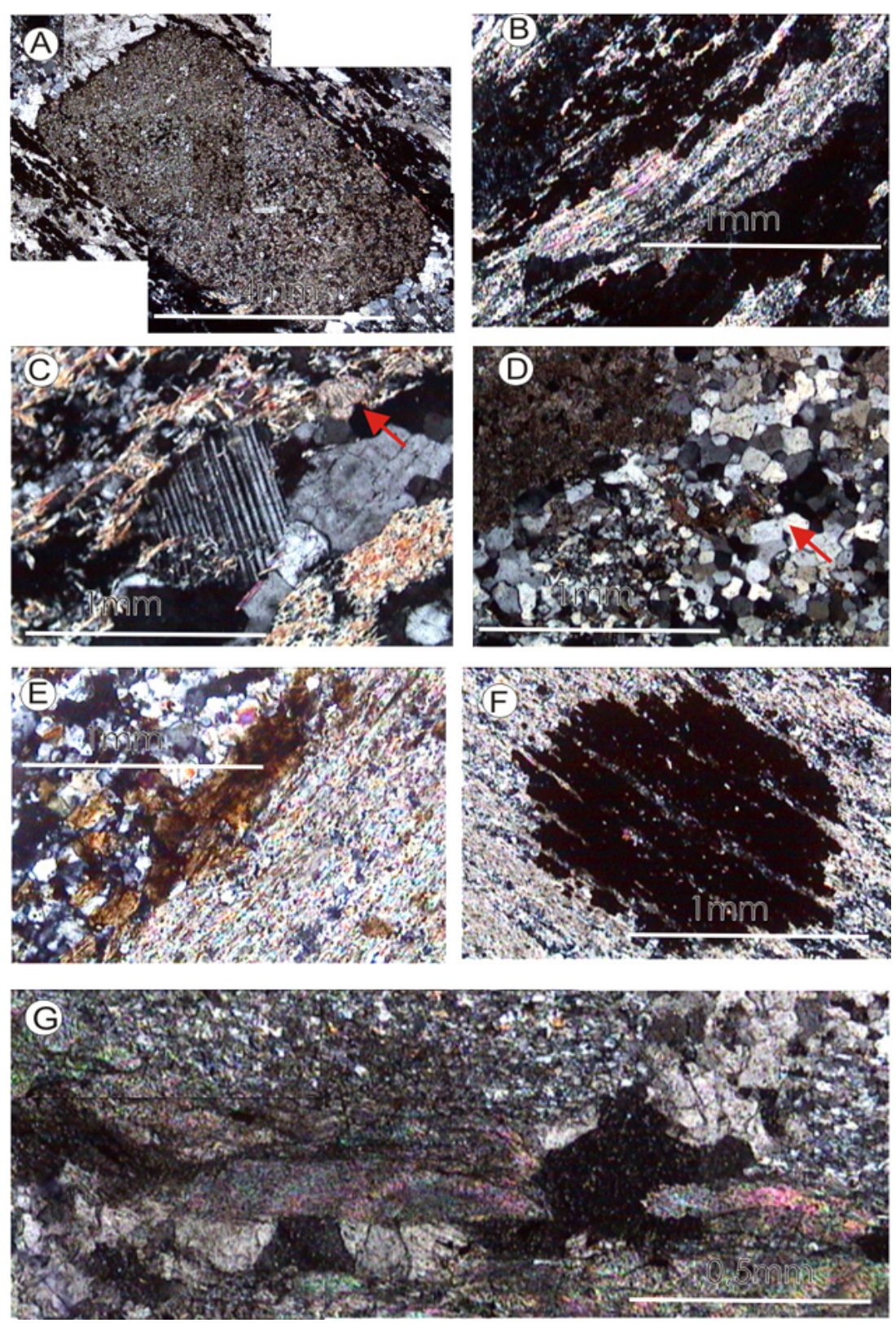

Figura 14 - Fotomicrografias dos metassedimentos da Fm. Acorizal no testemunho de sondagem FPO-05: A) Porfiroclasto de rocha carbonática em matriz lepidoblástica com sericita, quartzo e óxido de $\mathrm{Fe}$; B) Alternância de bandas sericiticas e bandas ricas em óxido de $\mathrm{Fe}$ em filito ferruginoso; C) Porfiroclasto de plagioclásio e de rocha carbonática (seta) na matriz de metaconglomerado; D) Blastese de biotita na matriz de metaconglomerado (seta); E) Niveis de biotita sin-cinemática alternando niveis quartzosos e sericíticos; F) Porfiroblasto de óxido de Fe, mostrando pré-existência em relação à clivagem metamórfica; $G)$ Porfiroclasto de rocha carbonática e preenchimento de fraturas por carbonato hidrotermal.

de magnetititos, resultado do possível aumento do $\mathrm{O}^{2}$ dissolvido na água do mar durante períodos de deglaciação, corroborado pela presença de clastos pingados a partir de massas de gelo flutuantes. A deposição da Formação Acorizal no Alinhamento Cangas-Poconé se deu em ambiente glácio-marinho, mostrando a existência de uma passagem gradual de um ambiente proximal na desembocadura de túneis sub-glaciais até distal em condições de mar aberto com deposição de ritmitos finos com clastos pingados, movimentos de massa subaquosos e chuva de material fino colocado em suspensão pela água doce da fusão das geleiras.

$\mathrm{O}$ estudo petrográfico revelou a proveniência dos detritos a partir de áreas fontes plutônicas (granitos, 
gnaisses, metabásicas) e supracrustais (quartzitos e rochas carbonáticas), além da imaturidade mineralógica dos protólitos, corroborando a hipótese de clima glacial. O metamorfismo é de Baixo Grau (Fácies Xistos Verdes) localmente atingindo a Zona da Biotita e a alteração hidrotermal é caracterizada por sulfetação, sericitização e carbonatação acompanhando o alojamento dos veios de quartzo aurífero. A macroestrutura do Alinhamento Cangas-Poconé difere do conjunto da deformação do Grupo Cuiabá na região, apresentando-se como um front de cavalgamentos e dobras recumbentes com foliação plano axial S1 apresentando baixos mergulhos para SE

A localização preferencial da mineralização na Fácies Cangas sugere a existência de forte controle litológico para a mesma, em adição ao controle estrutural já amplamente discutido em trabalhos anteriores (Paes de Barros 1998, Silva 1999, Silva et al. 2002, 2006, entre outros). Estas concentrações parecem ser o resultado da combinação de diferentes fatores para a efetividade do trapeamento dos fluidos hidrotermais sulfetados e auríferos: i) baixa permeabilidade dos ritmitos; ii) disposição estrutural das barreiras de permeabilidade S0 e
S1 em alto ângulo com relação à trajetória de migração dos fluidos; iii) presença de níveis ferruginosos funcionando como catalizadores da precipitação dos metais em solução no fluido. A presença de abundantes clastos de rochas plutônicas e metabásicas pode indicar que os fluidos hidrotermais podem ter sido gerados durante a Orogênese Brasiliana, pelo retrabalhamento térmico de um substrato fértil, aqui representado pelo Cráton Amazônico, seus granitos e seqüências vulcano-sedimentares como o Greenstone Belt do Alto Jauru.

Agradecimentos Aos geólogos André Luiz da Silva Molina e José Maria Gorjão da Luz, da Cooperativa dos Garimpeiros de Poconé (COOPERPOCONÉ), pelo apoio financeiro, liberação dos testemunhos de sondagem e acompanhamento na etapa de campo. Acompanhamentos são extensivos ao Sr Jonas Gimenez e sua irmã Selma pela gentileza pelo auxílio nas atividades de campo. Agradecemos também ao Departamento de Recursos Minerais da UFMT e ao discente de graduação Bruno Vasconcelos pela grande ajuda em trabalhos de reconhecimento geológico e descrição dos testemunhos.

\section{Referências}

Almeida F.F.M. 1948. Contribuição à geologia dos estados de Goiás e Mato Grosso. Rio de Janeiro, Notas preliminares da Divisão de Geologia e Mineralogia, DNPM, Boletim 46, p.1-15.

Almeida F.F.M. 1954. Geologia do Centro-Leste Mato-Grossense. Rio de Janeiro, DNPM/DGM, Boletim 150, 97p.

Almeida F.F.M. 1964. Geologia do Centro-Oeste Matogrossense. Boletim da Divisão de Geologia e Mineralogia, DNPM, Rio de Janeiro, Boletim 215, 123p.

Almeida F.F.M. 1965. Geossinclíneo Paraguai. In: Semana de Debates Geológicos, 1, Porto Alegre, Centro Acad. Est. Geol. Univ. Fed. Rio Grande do Sul, atas, p. 87101.

Almeida F.F.M. 1974. Sistema tectônico marginal do Cráton do Guaporé. Congresso Brasileiro de Geologia, 28, Porto Alegre, Anais, 4:11-17

Almeida F.F.M. 1984. Província Tocantins -setor sudoeste. In: Almeida F.F.M. \& Hasui Y. (eds.) O Pré-Cambriano do Brasil. São Paulo, Ed. Edgard Blucher, p. 265-281.

Almeida F.F.M. 1985. Alguns Problemas das relações geológicas entre o Cráton Amazônico e as faixas de dobramentos marginais a leste. In: SBG, Simpósio de Geologia do Centro-Oeste, 2, Atas, p.3-14.

Alvarenga C.J.S. 1984. Dobramentos da Faixa Paraguai na borda Sudeste do Cráton. Amazônico. In: SBG, Congresso Brasileiro de Geologia, 32, Rio de Janeiro, Anais, 7:3258-3271

Alvarenga C.J.S. 1988. Turbiditos e a Glaciação do Final do Proterozóico Superior no Cinturão Dobrado Paraguai, Mato Grosso. Revista Brasileira de Geociências, 18(3):323-327.

Alvarenga C.J.S. 1990. Phénomenes sedimentaires, structuraux et circulation de fluides à la transition Chaine-Craton: Example de la cote Paraguai dáge Proterozoique
Supérieur, Mato Grosso, Brézil. These Doc. Sci. Univ. dÁix Marseille, 177p.

Alvarenga C.J.S. \& Saes G.S. 1992. Estratigrafia e sedimentologia do Proterozóico Médio e Superior da região sudeste do Cráton Amazônico. Revista Brasileira de Geociências, 22(4):493-499

Alvarenga C.J.S. \& Trompette R. 1992. Glacially Influenced Sedimentation in the Late Proterozoic of the Paraguay belt (Mato Grosso, Brazil). Palaeogeography, Palaeoclimatology and Palaeoecology, 92:85-105.

Alvarenga C.J.S. \& Trompette R. 1993. Brasiliano tectonic of the Paraguay Belt: the structural development of the Cuiabá region. Revista Brasileira de Geociências, 23:18-30.

Amaud E. \& Eyles C.H. 2006. Neoproterozoic environmental change in the Port Askaig Formation, Scotland: Climatic vs tectonic controls. Sedimentary Geology, 183:99-124

Barros A.M., Adalberto R.H., Cardoso O.R.F.A., Freire F.A., Souza Junior J.J., Rivete M., Luz D.S., Palmeira R.C.B., Tassinari C.C.G. 1982 - Folha SD.21 Cuiabá, Projeto RADAMBRASIL. Levantamento de Recursos Naturais. Rio de Janeiro, Ministério das Minas e Energia. v. 26, p.25-192.

Brito Neves B.B.de 1999. América do Sul: quatro fusões, quatro fissões e o processo acrescionário andino. Rev. Bras. Geoc., 29(3):379-392.

Castelnau F. de. 1857. Expedition dans les parties centrales de l'Amerique du Sud, 15 vol., 7 partes, Paris.

Coussot P. \& Meunier M. 1996. Recognition, classification and mechanical description of debris flow. Earth-Science Reviews, 40:209-227.

Eyles C.H. \& Eyles N. 2000. Subaqueous mass flow origin for the Lower Permian diamictites and associated facies of the Grant Group, Barbwire Terrace, Canning Basin, 
Western Australia. Sedimentology, 47:343-356.

Evans J.W. 1894. The Geology of Mato Grosso. Quaterly Journal (Geological Society of London), 50:85-104.

Figueiredo A.J.A. \& Olivatti O. 1974. Projeto Alto Guaporé. Relatório final integrado. DNPM/CPRM Goiânia, v.1, $173 p$.

Hasui Y., Tassinari C.C.G., Siga Jr. O., Teixeira W., Almeida F.F.M. de, Kawashita K. 1980. Datações Rb-Sr e K-Ar do centro-norte do Brasil e seu significado geológicogeotectônico. Congresso Brasileiro de Geologia, 31, Camboriu, Anais, 5:2659-2667.

Hennies W.T. 1966. Geologia do centro-norte matogrossense. Dissertação de mestrado, Escola Politécnica da Universidade de São Paulo, 65p.

Lacerda Filho J.V., Abreu Filho W., Valente C.R., Oliveira C.C., Albuquerque M.C. 2004. Geologia e recursos minerais do estado de Mato Grosso. Programa Geologia do Brasil, CPRM/MME/SICME. Relatório final, 200p.

Litherland M., Annells R.N., Appleton J.D., Berrange F., Fletcher C.J.N., Hawkins M.P., Klinck B.A., Llanos A., Mitchell W.I., O'Connor E.A., Pitfield P.E.J., Poer G., Webb B.C. 1986. The geology and mineral resources of the Bolivian Precambrian shield: British Geol. Surv. Overseas Memoir 9, 153p.

Luz J.S., Oliveira A.M., Souza J.O., Motta J.J.I.M., Tanno L.C., Carmo L.S., Souza N.B. 1980 - Projeto Coxipó. Relatório Final. Companhia de Pesquisa de Recursos Minerais, Superintendência Regional de Goiânia, DNPM/ CPRM, v. 1, 136p.

Martinelli C.D., Xavier R.P. \& Batista J.J. 1997. Modelo estrutural e fluidos da mineralização aurífera "Garimpo dos Araés"-Nova Xavantina-MT. In: Simpósio de Geologia do Centro-Oeste, 6, Cuiabá, Anais, p.46.

Martinelli C.D. 1998. Petrografia, estrutural e fluidos da mineralização aurífera dos Araés-Nova Xavantina-MT. Tese de Doutoramento, Universidade Estadual Paulista, Rio Claro, $183 \mathrm{p}$.

Martinelli C.D. \& Batista J.J. 2003. Estratigrafia da seqüência metavulcanossedimentar dos Araés: Grupo Cuiabá? In: Simpósio de Geologia do Centro-Oeste, 8, Cuiabá, Anais, p.124-125.

Narbone G.M. \& Aitken J.D. 1995. Neoproterozoic of the Mackenzie Mountains, northwestern Canadá. Precambrian Research, 73(1-4):101-121.

Olivatti O. \& Ribeiro Filho W. 1976. Projetos centro-oeste de Mato Grosso, Alto Guaporé e Serra Azul. Relatório Final. CPRM, Goiânia 127p.

Paes de Barros A.J., Costa J.L.G., Resende W.M. 1998. Tipologia das mineralizações auríferas da Fazenda Salinas, Poconé, MT. In: Congresso Brasileiro de Geologia, 40, Belo Horizonte, Bol. de Resumos, p. 235.
Pinho F.E.C. 1990. Estudo das rochas encaixantes e veios mineralizados a ouro do Grupo Cuiabá, na região denominada "Garimpo dos Araés" Nova Xavantina, estado de Mato Grosso. Dissertação de Mestrado, Centro de Pesquisas em Geociências da Universidade Federal do Rio Grande do Sul, Porto Alegre, 114p.

Pires F.R.M., Gonçalves F.T.T., Ribeiro L.A.S., Siqueira A.J.B. 1986. Controle das mineralizações auríferas do Grupo Cuiabá, Mato Grosso. In: Congresso Brasileiro de Geologia, 34, Goiânia, 5:2383-2395.

Ribeiro Filho W. \& Figueiredo A.J.A. 1974. Reconhecimento geológico da região oeste de Mato Grosso. Congresso Brasileiro de Geologia, 28, Porto Alegre, 4:17-35.

Ribeiro Filho W. Luz J.S. \& Abreu Filho W. 1975. Projeto Serra Azul. Reconhecimento geológico. Relatório Final, DNPM/CPRM, Goiânia, v. 1, 104p.

Schobbenhaus Filho C., Oguino G., Ribeiro D.L., Oliva L.A., Takanohashi J.T. 1975. Folha Goiás SD 22. Carta Geológica do Brasil ao milionésimo, DNPM, Brasília, Brasil.

Silva G.G., Lima M.J.C.de, Andrade A.R.F.de, Issler R.S., Guimarães G. 1974. Folha SB 22 Araguaia e partes da Folha SC 22 Tocantins. Rio de Janeiro, Projeto RADAMBRASIL, Ministério das Minas e Energia, Levantamento de Recursos Naturais, v. 4, p. 22-131.

Silva C.H. 1999. Caracterização Estrutural de Mineralizações auríferas do Grupo Cuiabá, Baixada Cuiabana (MT). Dissertação de Mestrado, Universidade Estadual Paulista, Rio Claro, 134p.

Silva C.H., Simões L.S.A., Ruiz A.S. 2002. Caracterização estrutural dos veios auríferos da região de Cuiabá, MT. Revista Brasileira de Geociências, 32:407-418.

Silva C.H., Simões L.S.A., Ruiz A.S., Barbosa E.S. 2006. Província aurífera Cuiabá-Poconé- estágio atual do conhecimento geológico dos depósitos de ouro. In: Fernandes C.J. \& Viana R.R. (eds.) Coletânea geológica de Mato Grosso. Províncias e distritos auríferos de Mato Grosso. Ed. UFMT, v.2, p.35-51.

Trompette R. 1994. Geology of western Gondwana (2000500Ma). Pan-African-Brasiliano aggregation of South America and Africa. Balkema, 350p.

Unrug R. 1997. Rodinia to Gondwana: The geodynamic map of Gondwana supercontinent assembly. GSA Today, 7(1):1-6.

Vieira A.J. 1965. Geologia do Centro-Oeste de Mato Grosso. Petrobrás/DEBSP. Relatório Técnico 303, 58p.

Manuscrito ID 11456

Submetido em 13 de junho /2008

Aceito em 17 de dezembro de 2008

Sistema eletrônico de submissão 